\title{
Exploration of College English Teaching Reform under the Model of Application-oriented Talent Cultivation
}

\author{
Xiujie Peng \\ Dongfang College, Shandong University of Finance and Economics, Taian Shandong Province, \\ 271000
}

Keywords: applied talents; higher education; English teaching, curriculum reform

\begin{abstract}
As reform and opening up entered a new era, the talents cultivated under the traditional model were challenged by the new economic development methods, and society's demand for applied talents increased greatly. This requires us to turn our attention to the cultivation of new types of applied talents, at the same time colleges and universities as a frontline for cultivating talent should do a good job in teaching reform. This article starts from studying the inherent disadvantages of current college English teaching, and explores how to reform English teaching as a new way of training applied talents.
\end{abstract}

\section{Introduction}

With the transformation of China's economic development mode and the increasingly close contact among various countries in the context of economic globalization, in order to facilitate the exchanges of other countries in the world, the development of more applied talents that can speak good English has become an imperative and an urgent need and it has been putting forward claim for college English teaching . Traditional college English teaching emphasizes theoretical teaching . It only cares about the improvement in textbook learning and achievement and ignores the cultivation of practical skills. Under this teaching mode, students lack basic skills and can only be eliminated by the society. Therefore, teaching reforms should cultivate applied skills, reform teaching methods and teaching objectives, and provide society with new types of applied talents .

\section{Inherent Drawbacks in Current College English Teaching}

\subsection{Backward Rigid Education Concept}

A common view in college teaching is that liberal arts is a learning theory, engineering is the study of practical skills, and it is sufficient as a liberal arts student to study textbook knowledge. This oversimplified, one-size-fits-all view breaks the link between English learning and practical application, but it is very misleading to teachers and students. However, most colleges and universities still take the examination as the main purpose. Teachers neglect the cultivation of English comprehensive ability. Classroom teaching only takes textbooks as the core content. It places too much emphasis on vocabulary and grammar and other examination skill exercises; students' learning attitudes are generally not correct. The goal is to improve performance as the ultimate goal to ignore the cultivation of English application ability. Most students are committed to improving their test-taking skills. Under such circumstances, students lack the attitude and enthusiasm of life-long learning to meet the degree certificates at the college English test Band Four and Six level. If they lack the correct understanding of English learning, they will take the wrong direction even if they make efforts.

\subsection{A Single Boring Teaching Method}

The teaching result is determined by the teaching purpose and teaching method. The choice and application of teaching methods directly influences the final teaching effect. According to the author's observation, the teaching method of English classroom in our country has a single and unchanging teaching method. Most teachers spend very little time or even do not specialize in classroom teaching methods. At the same time, classroom interaction is also very limited . It is 
limited to teachers' unilateral teaching and students ' unilateral studies. Although the concentration of college students is better than that of students of other ages, boring classrooms cannot mobilize students ' active thinking. The teacher imparts knowledge of books in a single way, while students passively accept rigid contents. In the past, the enthusiasm for students for learning was seriously impaired in the past. The level and quality of such English class teaching is low , and its teaching effect is very limited. For example, in New Horizon College English three unit4 Five Famous Symbols of American, most of the teachers only talk about the contents of the textbooks. However, this class has many interesting parts, such as the American Revolution and Civil War are deserved to study .

\subsection{Unreasonable Course Setting}

The university's English course has long been defined as a basic course of higher education. The goal is to become proficient in mastering English basic knowledge and skills. This is very different from the development of undergraduate colleges that employ applied talents in various disciplines. The basic contents of the traditional English class are reading, writing, translation and listening and speaking classes, neglecting the cultivation of comprehensive English language proficiency. This type of course setting is lacking in rationality and can neither meet the basic needs of students nor adapt to the continuous new requirements for personnel training with the development of social economy. English should be a tool discipline with strong practicality. English learning can be accompanied by a person's life and people can benefit greatly. On the contrary, irrational curriculum setting neglects to provide students with practical application opportunities and cannot cultivate students' comprehensive English ability.

\section{Specific Measures for Cultivating Applied English Talents through Teaching Reform}

\subsection{Updated English Teaching Concept}

English teaching reform in colleges and universities should first be changed from the concept of education and teaching. It is necessary to change the traditional notion of teaching value that places more emphasis on test scores and turn to the cultivation and training of students' comprehensive ability in English comprehensiveness [1]. Special attention should be paid to the fact that English is not only a subject, but also the most widely used language in the world today. Learning English well has great significance for all aspects of communication and cooperation between different cultures. Therefore, colleges and universities in China as high-quality personnel training bases should actively take the initiative to change the backward and outdated traditional education concept, constantly update the college English teaching concept according to the needs of economic and social development, and improve the students' comprehensive English application ability. The most important thing is to do special teaching and training according to the individuality of students. Always adhere to the student's main status, inspire self-confidence and interest in their English learning, and improve their English comprehensive ability.

\subsection{Innovative Teaching Methods}

The traditional English classroom has long neglected the students ' main status, so that students as the subjects of learning can not play their main role, which directly affects in the unsatisfactory level and quality of college English teaching [2]. Therefore, the primary task of improving the quality of teaching are to reform and innovate boring traditional teaching methods and to develop new classes that are more efficient and more dynamic. The innovation of teaching methods can be achieved by introducing modern multimedia technology into the classroom. This not only stimulates students' interest but also conveys knowledge to students in a more intuitive and flexible way through the advantages of multimedia technology, breaking the limitations of traditional English classrooms . Control, allowing students to learn autonomously . The cultivation of applied talents should be used as a guide to innovation and reform, and students' English comprehensive ability should be improved through innovative teaching methods. For example, in the classroom, 
various types of open-faced activities, such as English drama performances, English recitations , and group discussions, are used to stimulate learning enthusiasm, improve application skills, and cultivate critical thinking habits. Some classic English plays or novels can be used for us, such as Shakespeare's " Romeo and Juliet ", " A Midsummer Night's Dream " , " The merchant of Venice ", and so on , which can not only help improve the English level but also increases from reading or performing .

\subsection{In-depth Study of Course Settings}

The curriculum should be based on language and culture-related knowledge, practical application skills, and oral communication skills, and gradually form a compulsory and elective complementary curriculum system. Listening and speaking ability is the core and key to the English application ability. Reforming the English course setting should begin with cultivating the practical application abilities so that students can use English through proficiency in their future work and communication. When setting up a course, you can't follow the old steps and follow the steps of the textbooks. You can learn English courses in stages, such as Basic English, Professional English, and Workplace English., Under the big stage, it is divided into several templates for modular teaching. You can also make use of the English language teaching resources on the Internet to build a resource library or develop learning software so that English learning is no longer confined to the classroom and has a closer relationship of life [3]. Strengthen the interaction between teachers, students and classmates so that students can speak more English and improve their sense of accomplishment and self-confidence.

\subsection{Improve the Level of Teachers}

The level of teachers in a school directly affects the school's teaching effectiveness and affects the level of personnel training in the school . Establishing a team of English teachers with abilities that is both talented and talented is a prerequisite for cultivating high-quality talent. While formulating policies to attract young teachers with new concepts, we must also adhere to the importance of existing teams, organize various types of training, especially overseas training and seminars to increase the professional knowledge of the teaching staff, and continue to encourage teachers to innovate . Educational philosophy, research teaching methods, exploration of education reform orientation [4]. Such as vigorously cultivating innovative teachers, to promote the construction of teaching research team ; regular advanced training of English teachers, to absorb advanced teaching methods and ideas. Such a team of teachers can cultivate new talents for the new era .

\section{Conclusion}

In summary, the reform of college English education is to train new talents and adapt to the needs of economic and social development. All education departments should spare no effort to implement the end. It is even more important to note that the reform of university teaching involves profound research on all aspects of education and education. It should be studied comprehensively. It cannot be done overnight. Long-term planning should be formulated and implemented. Only in this way can we achieve the goal of cultivating new applied talents for the society.

\section{References}

[1] Yan Li. On the Reform of College English Teaching in the Perspective of Practical Talent Cultivation [J]. Education Observation (First Half). 2016 (03)

[2] Jiang Yingying, Ji Zhemin. Research on College English Teaching Reform under the Model of Applied Talent Cultivation [J]. Journal of Jilin Provincial Institute of Education (early). 2015 (02)

[3] Lu Shaoquan. Reform and Research of College English Teaching Model under the Framework of Applied Talent Cultivation [J]. Occupational Technology. 2012(06) 
[4] Pan Yinghui. Exploration of College English Teaching Reform under the Model of Applied Talent Cultivation [J]. Journal of Changzhou Vocational College of Information Technology. $2012(02)$

[5] Zhang Li. The Improvement of Translation Theory and Practice in Translation Teaching in Colleges and Universities [J]. Science and Technology Information. 2016 (30)

[6] Zhang Li. Application of Semantic Symbol Pattern in College English Translation Teaching [J]. Science and Technology Information. 2016 (32)

[7] Yang Wenyu. Research on Optimization of College English Teaching Model Supported by Information Technology [J]. Science and Technology Information. 2016 (30) 